\title{
On the Origin of the 'Private Sphere': A Discourse Analysis of Religion and Politics from Luther to Locke
}

\author{
CRAIG MARTIN \\ St. Thomas Aquinas College
}

\begin{abstract}
This essay supplements the recent literature on the social construction of 'religion' by demonstrating that liberal discourses on the 'private sphere' and the 'separation of church and state' originated in a rhetorical slippage between different uses of the word 'religion' in early modern Europe. However, contrary to much of the recent social constructionist literature, this essay demonstrates that the implementation of the so-called 'separation of church and state' resulted not in an actual separation, but, rather, that this discourse masks the very real circulation of power from one institution to the other.

Keywords: Social Construction of Religion, Early Modern Political Theory, Privatization of Religion, Liberal Discourses on Religion, Liberal Political Theory, Separation of Church and State
\end{abstract}

We should not accept at face value the distinctions that are so valued within political philosophy and everyday life between the public and the private, only then to ask why and to what extent the boundary has been inappropriately transgressed. [...] We need instead to examine how the very idea of the private sphere was formed. (Miller \& Rose 2008, 19.)

The thesis of this essay is that liberal discourses on the 'private sphere' and the 'separation of church and state' originated in a rhetorical slippage between different uses of the word 'religion' in early modern Europe. In addition, I argue that the discourse on the separation of church and state did not result in an actual separation, but rather that this discourse masks the circulation of power from one institution to the other.

These claims challenge a certain popular view of the origins of religious tolerance and the separation of church and state. The popular view, often defended by liberals praising the triumph of individual freedom over coercive theocracy, looks something like the following narrative: Jesus himself 
argued that 'religion' and the 'state' should keep separate their domains when he ordered that his followers 'give to Caesar what is Caesar' $s$ '. Thus Jesus instituted a distinction between the 'spiritual' realm, which concerned individuals' relationships to God, and the 'temporal' realm, which concerned individuals' relationships to the local governor of 'this world'. ${ }^{1}$ However, Christians began to violate this stricture when, as a group, they took control of state functions in the Roman Empire, after the conversion of Emperor Constantine. The two spheres then began to overlap or coincide, and unfortunately remained imbricated until those seeking toleration after the Protestant Reformation recovered and reinforced the normative distinction between the 'spiritual' and the 'temporal' realms. Once this happened, governments ceased their illegitimate interference with 'religious matters'. The 'liberty of conscience' that followed was thus conditioned by the appropriate separation of church matters from state matters, or the separation of 'faith' from 'civil' matters. This culminated, in the apogee of toleration writings, with John Locke's greatly influential 'A Letter Concerning Toleration', which did not contain original arguments as much as 'laboured restatements of old positions'; that is, Locke merely summarized and put down in writing the position that had already become broadly persuasive (Kamen 1967, 231). In sum, Europe began its modern period with unnecessary religious violence and intolerance, but by the end of the seventeenth century Europe would be better described by the success of discourses on tolerance, the institution of freedom of conscience, and the separation of church and state.

One can find this myth in a variety of popular works, and sometimes in academic works. The myth is more frequently found in older writings (see Kamen 1967; Lecler 1960), but also in more recent ones (see Gauchet 1997; Zagorin 2003); the political philosopher John Rawls seemed to hold a form of this myth (see Rawls 1996). Some recent works, such as Benjamin J. Kaplan's Divided by Faith, are much less romantic; Kaplan recounts a similar version of this myth in his introduction, but then follows it up with the following: 'Such is the story we tell ourselves - the history of religious tolerance and intolerance in a nutshell' (Kaplan 2007, 2). He goes on to suggest the ideological work that is done when we tell this story to ourselves:

1 It is difficult to see how a suggestion attributed to Jesus in the New Testament that Jews should pay taxes to the Roman Empire could serve as the basis for a modern political philosophy. In addition, the appeal to the authority of Jesus in this narrative seems to undermine the goal sought by those who tell it - is the New Testament an authority all should accept as the basis for state policy? 
[L]ike similar ideological constructs, the 'rise of tolerance' has a circular, self-confirming power. It provides the standard against which we judge our societies - severely sometimes - and lends moral weight to calls for greater tolerance. On the other hand, its chauvinism can be paralyzing. By blaming intolerance on primitive irrationality it obscures its true causes. And since no people want to consider themselves primitive, it encourages us to view intolerance as someone else's vice, not our own. (Kaplan 2007, 6.)

For Kaplan this myth is one that makes it easy for us to judge others and to view ourselves as righteous by contrast. I have no doubt that this myth can do this sort of work, but in this essay I'm interested in a different sort of work this myth does: I want to see how it distorts or masks the relationship between 'religion' and 'politics', which, according to the myth, are different things that are or ought to be separated from one another in modern liberal democracies. Even Kaplan himself uses language that vaguely implies religion and politics are essentially separate things, as Chapter four of his book is titled 'One Faith, One Law, One King: How Religion and Politics Intersected', and in one chapter he says that 'civic and sacral community overlapped in [...] complex ways in cities' (Kaplan 2007, 62). While one cannot be certain, this language seems to imply that religion and politics are separate things that unfortunately crossed one another during this time period (I don't want to draw any firm conclusions from a chapter title and a few scattered quotes; this seemingly essentialist language does not appear very often in Kaplan's book, so I'm not sure he intends it in an essentialist manner).

Contrary to the popular myth I am attempting to dismantle, I will characterize this shift in Europe not as one from theocratic coercion to religious freedom but as a shift from one Christian discursive regime to a different Christian discursive regime, in which Christian norms and ideology continued to operate as authoritative for the state. From this perspective, the triumphal liberal account is misleading insofar as it largely ignores the extent to which the norms and ideologies produced by Christian institutions continued to operate as authoritative even within the liberal regime. If this is the case, however, how can we account for the popularity of the myth? In order to answer this question, I first defend my alternate view - there was no partition of 'religion' from the 'state' during this time period - and then argue that the continuing (although altered) relationship between these institutions was masked by a rhetorical mechanism rooted in the very same discourses on the 'two spheres' doctrine. 
There is a great deal of recent scholarship that has approached these issues from a Foucauldian, social constructionist perspective. (By 'social constructionist perspective' I merely mean the perspective that views words, rhetorical strategies, and ideologies as the building blocks we use to create or construct our world; my view on these matters - if not my vocabulary - is very close to Ian Hacking's [cf. Hacking 1999]). These scholars do not take for granted the natural existence of a private, religious sphere and a public, secular sphere, which first unfortunately overlapped and later were rightly extricated. Although their views are substantially different from one another in many respects, these theorists seem to share in common the view that the religion/secular distinction did not pre-exist modernity, but is a product of it (see McCutcheon 2003, 252ff; Carrette \& King 2005, 14; Lincoln 2003, 58ff; Asad 1993, 40ff; Arnal 2001; Fitzgerald 2003, 2007a, 2007b). As Timothy Fitzgerald puts it in Discourse on Civility and Barbarity (2007a), there is no such thing as 'religion' built into the nature of the universe; he claims in the introduction that his book is intended as 'a critical history of 'religion' as a category, in the hope of showing that far from being a kind of thing or an objective and observable domain [...], religion is a modern invention' (Fitzgerald 2007a, 6). He goes on to say that 'words create worlds' (p. 68), and that 'religion and politics today have been defined [in a way] that make them mutually exclusive and inhabiting distinct domains' ( $\mathrm{p}$. 173). The invention of modern discourses ushered in 'new configurations [which replaced] previous categories and configurations. This is a change of cosmology.' (P. 186.) Unfortunately, these 'two distinct domains are essentialised and transformed into the nature of things' (p. 289). Although categories do not have fixed meanings (p. 23), we often become accustomed to the local way of organizing the world and think that that is the way the world naturally is. We assume that the categories we use to order the world actually reflect the eternal order of the universe - we mistake our local social order for the world itself. The distinction between a religious and a secular sphere is not built into the nature of the universe, but is unique to the modern period.

According to this view, it is not that 'religion' was separated from the 'state'; rather, the very distinction between private and public was a modern, European invention that served to reorder European society in new and unique ways. In Fitzgerald's words, '[t]he secular as the modern 'nonreligious' was not a preexisting domain that, having been under the control of the church, now in modernity has changed position and become dominant'; on the contrary, 'something new was invented' (2007a, 68; emphasis mine). The 
social constructionist interest in this genealogy is, in part, related to the point that, since the religion/state distinction was an ordering principle unique to modern western culture, it cannot be used to describe non-western cultures without distortion.

Although I agree with much of this recent scholarship (in particular, I am indebted to Russell McCutcheon's reading of public/private discourses in The Discipline of Religion), I depart from - or perhaps supplement - their conclusions in one important way. I will argue that the religion/state or public/private distinction did not create a privatized religion, nor did it separate, segregate, or insulate the state from religion - as many of these social constructionists (especially McCutcheon, Arnal, and Fitzgerald) suggest or imply - but rather that it had the effect of masking the circulation of power from one to the other. For instance, contrary to what Fitzgerald claims, words did not create worlds in this case; 'religion' and 'politics' as separate domains were not 'invented as part of the same rhetorical movement' (15-6; see also 186, where Fitzgerald talks of 'new configurations') - they were not invented at all. That is, there was no separation or bifurcation of Christian institutions from state institutions, although the use of the 'two spheres' language made it appear as if there had been one. In a sense I am overstating my disagreement with McCutcheon, Arnal, and Fitzgerald - I doubt they would insist that the invention of this rhetoric created any sort of absolute division between discrete public and private spheres. However, they do tend to emphasize that this new ideology created the differences it presumed to identify, whereas I want to emphasize the extent to which this new ideology masked the imbrication of what it presumed to identify.

As I will show, some accounts of the transformations that took place between Luther and Locke rely all too often on the terms and chains of rhetorical associations that belong to the discourses they attempt to explain, and in doing so take for granted that there was a separation of religion from the state in the early modern period. Consequently, these accounts are unable to expose the ideological function of the religion/state binary, the way in which the content of these terms was manipulated by early modern theorists, or the regime of social relations they tend to obscure. In order to bring into relief the nature of the social changes that took place, as well as the relationship between those changes and the discourses used to bring them about, I will scrutinize the literature from this time period to show the following: first, what did not change in the discourses on religion and politics from Luther to Locke, and, second, what did change in these discourses - in each case focusing on the social relations these discourses 
justified or legitimated. As I have already suggested, my conclusion will be that despite the real changes that took place, the hegemony of Christian ideology in determining and justifying the shape of the state and its functions was quite constant. In addition, the religion/state taxonomy, which developed out of the 'two spheres' doctrine, masks this fact and is therefore not a particularly useful tool for understanding the changes that took place; to characterize this period as simply marked by the rise of a 'separation of church and state' is ultimately misleading.

\section{Other Preliminaries}

Before beginning, let me offer several caveats. First, I am not attempting to contribute to early modern history. Rather, what I am trying to do is show the rhetorical effects of the discourses on religion produced during this time period - which we have inherited.

Second, Foucault's mode of discourse analysis, his genealogical approach, tends to be dismissive of 'origins'. It would seem that I've missed the point by using Foucault's method to search out the 'origin' of modern discourses on religion. However, what Foucault rejects about origin stories is the idea that the origin of something is more pure or more authentic than present iterations. I agree: I think that trying to find out what the word 'religion' originally meant to the people who first used it (in Latin) will tell us little if anything about discourses on religion today. Nevertheless, almost all of Foucault's books are designed to point out innovative shifts in discourse: at some point in time people used this discursive regime, but then they switched to using these words differently (or to other words), with these effects. This is what I am trying to show: there were rhetorical innovations during the early modern period that shifted the way in which the terms 'religion' and 'state' were used - and which I believe have had relatively stable uses in mainstream liberal political theory ever since. So my search for the 'origin' of the language of the 'private sphere' is not designed to get back to some pure essence, but to investigate the discursive shifts that took place in the early modern period brought us to where we are today.

Third, in this section I consider a number of different authors and political actors in different countries, different centuries, and different political situations. I make no apology for roaming back and forth between them without much attention to their specific social contexts. I am not doing history here - I am doing discourse analysis. I do not intend to show causality or the influence of one author on another; I do not think that that sort of 
investigation would be useful or helpful. Instead, what I want to show is that during the time period between Luther and Locke there developed a relatively stable way of talking about religion and politics, and that this way of talking distorts more than it reveals. Discourse analysis of this sort is the bastard stepchild of structuralism: it rejects structuralism's insistence that discursive regimes and rhetorical oppositions are ahistorical and universal, but follows structuralism by insisting we should be extremely attentive to conceptual schemes. I need not demonstrate that Luther influenced (or did not influence) Locke, or that they were in different (or similar) social contexts, in order to perform an analysis of the similarities or differences of their conceptual schemes.

Fourth, I want to draw attention to the fact that for the purposes of this paper I am completely ignoring the work of secularization theorists and philosophers such as Charles Taylor or José Casanova. This is not because I think their work is unimportant or irrelevant, but because in this particular article my purpose is to draw attention to blind spots in the concepts they take for granted.

Fifth, I want to take a moment to situate my argument in relationship to Timothy Fitzgerald's argument in Discourse on Civility and Barbarity (2007a), especially since that book covers the same topic as this article (the creation of discursive binaries related to 'religion') during the same time period (the fifteenth and sixteenth centuries). Despite a few quibbles with the details of his argument (see Martin 2008), I am largely in agreement with Fitzgerald. The contemporary distinctions between 'religion' and 'politics', 'economics', or 'secularism' - which were created during this time period - are ideological insofar as they sometimes tend to naturalize the 'secular' sphere as an ideologically neutral and objective space. This reproduces the interests of some groups at the expense of others. We are not describing the world by using these terms, but are in some cases reproducing those interests. In addition, Fitzgerald is right to insist that these terms cannot be understood in isolation; we cannot understand how a word like 'religion' is used unless we understand how it is not used. In this essay I am specifically concerned with how religion is configured as the 'other' of politics, the state, or the public sphere.

My analysis largely diverges from Fitzgerald's in two ways. First, as I've already suggested, I suggest Fitzgerald overstates the extent to which 'words create worlds'. Second, the stakes of our arguments are quite different. Fitzgerald seems primarily interested in showing how discourses on 'religion' and 'politics' are utilized in support of imperialist, colonialist, 
or positivist projects; by contrast, I'm primarily interested in showing how these discourses are utilized to secure 'religious' institutions the right to socialize citizens (through the work of families, churches, etc.) by portraying such work as a 'private matter', while simultaneously masking the fact that those 'private matters' have an incredible 'public' significance. Fitzgerald is more concerned with showing how the 'secular sphere' is made to be seen as ideologically neutral in relation to the 'religious sphere', whereas I am interested in showing how the 'religious sphere' is made to be seen as apolitical. My agenda has therefore more narrowly directed my attention to those parts of fifteenth and sixteenth century writings that justify or utilize the public/private binary. Because of this narrow focus, my argument intersects with only parts of Discourse on Civility and Barbarity.

Sixth, what do I mean when I use the terms 'Christian', 'religion', or 'politics'? What I want to show in this essay assumes, of course, that these were contested concepts during this time period. By using these concepts am I circularly imbricating myself in a process of naturalizing these terms? Fitzgerald suggests in Religion and the Secular that any talk about the relation between politics and religion in the fifteenth century necessarily 'smuggles in a tacit assumption that in the fifteenth century "religion" and "politics" were conceived as essentially separate entities or domains capable of having an impact on each other' (Fitzgerald 2007b, 212). As a result, he dismisses as anachronistic or ideological not only second-order use of the concepts 'religion' and 'politics' when talking about fifteenth century Europe, but all scholarly second-order uses of the word 'religion':

The idea that scholars can choose to mean what they like by 'religion', as though we can simply say that 'this is what we intend to mean by "religion" for analytical purposes', seems highly questionable, and yet it is a widespread rhetorical ploy. One only has to consider the usages of the term in the media, in politics and in popular discourse to realize that no one has control over its meanings. (Fitzgerald 2007b, 11.)

However, saying what one intends to mean for analytical purposes is not at all the same as saying that one intends to control the meanings of a term in general. The American government does not have control over all its citizens' uses of the term 'poverty', but the state does when it comes to being eligible for state benefits if one falls below the 'poverty line' as the state defines it. Fitzgerald argues something similar in Discourse on Civility and Barbarity: 
I have argued that we cannot use the term for descriptive and analytical purposes as though it is neutral, and as though its meaning is ours for the choosing, because it is still appropriated by powerful agencies and embedded in confused but disseminated discourses which have largely unacknowledged ideological purposes. (Fitzgerald 2007a, 298-9.)

However, all concepts are capable of appropriation - if we forbade the use of concepts on these grounds we would not be able to use any concepts at all. Whether or not it might be pragmatically useful to avoid a particular loaded term in a particular socio-historical context would be a reasonable discussion, but the claim that we should not, in principle, use a concept because it is capable of ideological appropriation is not persuasive to me. I do not control all uses of the word religion, but this is an insufficient reason why it would be illegitimate in some instances to proffer a provisional, second order use of a term for analytical purposes - so long as I am careful not to smuggle in the dubious ideological assumptions with which Fitzgerald is rightly concerned. Edward Said famously demonstrated that the modern distinction between 'the East' and 'the West' was coded in a way that served the interests of those identified as a part of 'the West', but one should not conclude, after reading Orientalism, that I am serving colonialist interests every time I say that my house is 'east' of the university. I do not think any and all uses of the word 'religion' smuggle in problematic assumptions, as Fitzgerald suggests, and careful uses of the term do serve legitimate purposes. This is a tricky business, as I'll be passing back and forth between discussing first-order uses of these terms and my second-order use, but I think I can do so with some degree of success (see Martin 2009 for an extensive discussion of how my philosophy of language contributes to how I think about and use words like 'religion').

Here are some explanations of my second-order uses of key terms. When I refer to 'Christianity', I am not making an authenticity claim - my purpose is not to distinguish 'true Christians' from 'inauthentic Christians'. On the contrary, I use the noun 'Christianity' and the adjective 'Christian' to refer to any group of people who self-identify as Christian, as well as to the rhetoric, ideology, texts, practices, etc. that are in some substantial way unique or special to them (I would call the New Testament, for instance, a Christian text; I would call the doctrine of the trinity a Christian doctrine). I use the noun 'state' to refer to an institution (or network of institutions) that holds a monopoly on the use of violence in a region, while I use the noun 'civil institution' to refer to institutions below the level of or along- 
side the state, but which do not have a monopoly on the use of violence. I use the term 'religion' to refer to those civil institutions (formalized or not) that are colloquially designated by the word 'religion', such as the Catholic church, the Southern Baptist Convention, Hindu temples in India, the Zen center in my hometown, etc. I apply the adjective 'religious' to the rhetoric, ideology, texts, practices, institutions, etc. that come from such civil institutions. Given such uses of these terms, I would refer to Christian churches, for instance, as both religious and civil institutions, although I could also say that Christian ideologies - which originate from and are distributed by Christian churches - may inform or legitimate the actions of the state. As I use these terms, 'religions' do not have any essence (spiritual, supernatural, apolitical, or otherwise), and I fully realize that the colloquial distinctions between civil institutions that are counted as 'religious' (the Catholic church, for instance) and those that are not (the Pearl Jam fan club, for instance) are often largely arbitrary. I do not claim that my use of the word 'religion' is what religion really is; it is simply the use I am presently making for pragmatic purposes.

Some contemporary theorists might respond with the following objection (I don't know if Fitzgerald would or not): 'using second order terms to describe societies in which these terms were not used is terribly anachronistic'. I both agree and disagree. On the one hand, words like 'religion' are in some cases social ordering principles -as when 'religion' is opposed to 'state' or 'politics'. It would be highly anachronistic to suggest that there was a separation of church and state in ancient Greece, for instance, at a time when these concepts did not exist and could not have been used as social ordering principles. On the other hand, not all second order uses of such concepts import these sorts of implications. Ancient Greeks did not have the concept of $\mathrm{H}_{2} \mathrm{O}$, but that doesn't mean that they didn't drink it. If I define religion in a way that does not imply it is a social ordering principle in the context in which I'm applying the concept, its use need not be anachronistic.

\section{What Did Not Change}

There are two key things that did not change during this time period. First, almost all political discourses relied on some form of the 'two spheres' doctrine. That is, it is not as if those who supported toleration were leveraging the two spheres doctrine against intolerant theocrats who opposed it. On the contrary, both those who opposed toleration and those who believed 
that Christian institutions should fall under the authority of the state relied on their own version of the two spheres doctrine. The debate is better described as a battle between competing views that imagined the structural relationship between of the two spheres in different ways.

Ideology produced by Christian institutions never ceased to serve as the implicit theoretical justification for the two spheres doctrine. The distinction between a 'spiritual realm' and a 'temporal realm', on which the two spheres doctrine relied, was based on a particular Christian anthropology. In general, this anthropology was rooted in broadly Augustinian ideas about the relationship between God and individual sinners. ${ }^{2}$ Because God extended grace to individuals, on the condition that they individually accept it of their own free will, the application of force in this matter was neither desirable nor sensible. ${ }^{3}$ The 'spiritual' realm concerned this free interchange between individuals and God, which had little to do with 'temporal' or 'worldly' matters. Only when individuals accepted, with their free will, God's offer of grace, could they be a part of the spiritual and invisible church. ${ }^{4}$

In one of Luther's early works, On Secular Authority, he develops this Augustinian project: "Faith is free, and no one can be compelled to believe" (Luther 1991, 26). In addition, 'it is impossible and futile to command or coerce someone to believe this or that' (p. 25). For this reason, '[s]ecular government has laws that extend no further than the body, goods and outward, earthly

2 The following sketch is very basic but is adequate for my purposes in this section, although I should mention that the reception of Augustine (and the spiritual/temporal binary in general) by the early moderns is much more complicated than I portray it here.

3 See Witte 2002, especially 94ff, and 101ff. Augustine's view on free will was first part of his theodicy, according to which God was released from responsibility for 'evil' because humans 'freely' chose to do evil. See Augustine 1964. For Augustine's views on grace, see Augustine 1997a, 1997b, and 1999. This anthropology was defended in the early modern period by the 'truism' that individuals cannot be forced to 'believe'. That is, the use of force will not guarantee conversion. Proof of this was provided by the many stories of those 'martyrs' who refused to recant under torture and threat of death. However, these sorts of examples prove little. The very idea that one cannot force people to change their beliefs must assume that beliefs are not simply chosen by free will - if beliefs were simply and freely chosen, then individuals could simply and freely choose to switch them at gunpoint. The fact that they cannot switch them at gunpoint implies that they are not simply and freely chosen. The fact that citizens cannot switch their beliefs at gunpoint is better explained with reference to the force of education and socialization than with reference to a doctrine of free will. Considered outside of a dubious Augustinian anthropology, the martyr's example is more likely to prove that one can force belief, if only through education and socialization.

4 Augustine himself vacillated between attributing humans' acceptance of grace to God and attributing it to human free will. The former claim supported his doctrine of God's omnipotence, but the latter was necessary to his theodicy; Augustine never found a way to reconcile the two. 
matters' (p. 23). In this work, Luther's argument depends upon soul/body, inward/outward, and spiritual/temporal realm taxonomies. (As I will demonstrate below, these are not homologous to the church/state taxonomy.)

There are at least two important qualifications to add. First, according to this Augustinian anthropology, what was 'spiritual' did not, in principle, include everything that could be associated with Christianity and Christian institutions. That is, what was spiritual involved one's individual relationship to God and God's offer of grace, but certainly not everything that might be associated with 'religion' generally.

Second, when it was claimed that force was inappropriate in 'religious' matters, in principle this meant only that one could not force an individual to accept grace, not that force was inappropriate in all 'religious' matters. Although this Augustinian view claimed that the state could not force individuals to accept grace, this fact did not necessarily prevent the state from providing the proper conditions in which it was possible for an individual to learn about true doctrine and true grace. For Augustine, this meant that the Donatists, whom he regarded as insidious heretics, could be forcibly controlled by the state. Perez Zagorin writes, ' $[w]$ hile no one could be made good against his will, the fear of punishment could persuade a person to repudiate a false doctrine and embrace the truth he had previously denied, as had happened to many Donatists who had thankfully become Catholics and now detested their diabolical separation' (Zagorin 2003, 30; see also Kaplan 2007, 25-6). For Luther and Calvin, this meant that the state could prohibit false teachings about grace and support true Christian education, particularly Christian moral education. According to John Witte, Jr., for Luther, the law should 'make people conscious of their duty to give themselves completely to God while at the same time making them aware of their utter inability to fulfill that duty without divine help' (Witte 2002, 103). In On Civil Government, Calvin writes, 'the end of secular government, [...] while we remain in this world, is to foster and protect the external worship of God, [and] defend pure doctrine and the good condition of the church' (Calvin 1991, 49).

This view does not commit Luther or Calvin to the belief that faith or the acceptance of grace can be forced; it only commits them to the belief that true faith can be freely accepted only in certain conditions. Again, Luther and Calvin's belief in a 'spiritual' realm, according to Augustine's anthropology, is entirely compatible with the recommendation that the state repress false doctrines. 'You can lead a horse to water, but you cannot make him drink', as the saying goes - but one can justifiably prevent brigands from stealing 
the horses away from the water. Thus the magistrate's repression of false doctrines would not, in principle, constitute a violation of the strictures of the two spheres doctrine in its Augustinian form. Despite this fact, many scholars make a special effort to contrast Luther's recommendation that false doctrines be suppressed with statements in which Luther claims that heretics cannot be converted by the sword (see, for instance, Zagorin 2003, 74). This contrast has a certain rhetorical effect for readers already persuaded of the necessity of 'religious freedom' in its contemporary form; however, Luther's apparently conflicting statements are inconsistent on this matter only if the purpose of the suppression of untrue doctrines is to convert heretics - if the purpose is to protect true believers from false doctrines, then Luther's commitment to the repression of heresy is not at all inconsistent.

It is important to qualify this point by noting that Luther varied his position on these matters. When his movement was young, and he was seeking toleration from princes who might suppress it, he did attempt to draw a justification for tolerance from the soul/body distinction. On Secular Authority, an early work, counters the claim that the use of the 'sword' can rightly be used to prevent 'people from being led astray by false doctrine' (Luther 1991, 30). In this passage, he suggests that secular authorities have one set of tasks and means, and church authorities have an altogether different set of tasks and means.

How [...] could heretics be restrained? The answer is: it is for bishops to do that; the task has been assigned to them and not to rulers. The use of force can never prevent heresy. Preventing it requires a different sort of skill. (Luther 1991, 30.)

Bishops oversee souls by means of persuasion, princes oversee bodies by means of the sword. However, when Luther's movement was more powerful, and when threats to his movement came from 'heretics' rather than princes, Luther abandoned these defenses of toleration and argued that heresy could rightly be repressed by the magistrate.

Calvin's corpus, on the other hand, is not marked by these vacillations. Calvin consistently remained a staunch defender of the magistrate's right to repress heresy. For him, the regulation of bodies included the regulation of heresy:

Civil order has not only to do with men's breathing, eating, drinking and flourishing [...]. Its concern, I say, is not only with these, but what is more, it 
prevents idolatries, sacrileges against the name of God, blasphemies against his truth, and other scandals to religion from emerging into the light of day and spreading among the people [...]. In short, it upholds a public form of religion amongst Christians. (Calvin 1991, 50.)

Calvin goes on to add that true religion must be prevented 'from being besmirched and violated with impunity by public and manifest sacrilege' (Calvin 1991, 50-1). He rightly understood that there was nothing contradictory in his insistence that the soul is free to choose grace, and that bodies must be prevented from corrupting civil order and seducing souls to hell with heresy, sacrilege, and immorality.

Many others who opposed tolerance or supported the state control of Christian institutions maintained this two spheres doctrine. John Knox insisted that Christian institutions should come under the control of the state, but continued to use a distinction between civil institutions, or civil magistrates, to whom is "given the sword for punishment of malefactors", and 'matters of religion', which, although different, should not be 'sequestered' from the former (Knox 1994, 87-8). Similarly, Richard Hooker insists that although his opponents believe he fails to distinguish the two, 'A Church and a Commonwealth we grant are things in nature the one distinguished from the other [...]. [They are] not distinguished only in nature and definition, but in subsistent perpetually severed.' (Hooker 1989, 129.) He clearly distinguishes between on the one hand the inward and invisible administration of the church by Christ, on the other the external and visible administration of the church by the 'head' of the visible church (p. 173-4). He explicitly uses the spiritual/temporal (p. 131) and soul/body (p. 154) binaries, although he denies that the spiritual/temporal binary is homologous to the church/commonwealth binary, insofar as he insists that the commonwealth must provide for both temporal and spiritual needs (p. 131-2). In other examples, Johannes Althusius divides his Politics into chapters on 'Ecclesiastical Administration' and 'Secular Administration', (Althusius 1964); Richard Baxter allocates 'Civil Power to Civil Rulers, and Ecclesiastical to Church-Rulers' (Baxter 1994, 130) and distinguishes civil rule 'by the sword' from pastoral rule 'by the word' (p. 167); and Spinoza distinguishes between a 'commonwealth' and 'religion' throughout the entirety of his Theological-Political Treatise (Spinoza 2001). In sum, the two spheres doctrine was not unique to the defenders of tolerance - it was present from the beginning of the early modern period and was employed by all. 
The second thing that did not change during this time period was that political discourses continued to rely on the claim that the magistrate must not tolerate threats to the public good, public welfare, or the commonwealth. This sort of argument took two different forms. One suggested that citizens' temporal welfare included or overlapped with their eternal welfare. Hooker suggests,

for of every politic society that being true which Aristotle hath, namely, That the scope thereof is not simply to live, nor the duty so much to provide for life as for means of living well, and that even as the soul is the worthier part of man, so human societies are much more to care for that which tendeth properly unto the soul's estate than for such temporal things as this life doth stand in need of (original emphasis; Hooker 1989, 131-2).

For Hooker, concern for the public welfare included a consideration of citizens' eternal welfare. Calvin similarly argues that while 'government and the spiritual and internal kingdom of Christ are distinct [...] they are in no way incompatible with each other' (Calvin 1991, 49). Although popular among those who opposed policies of tolerance toward dissention, this first form of the 'public welfare' argument was much less popular among the defenders of tolerance. The second form of the 'public welfare' argument suggested that the peace of a commonwealth, independent of any concern with eternal welfare, depended on the moral norms and virtues passed down by Christianity or the biblical tradition. Subversion of 'true religion', 'natural religion', or the Christian 'moral law' was consequently seen by many as punishable on the grounds that it was politically subversive, rebellious, or seditious. In a fit of hyperbole that provides us with an ideal type of this sort of argument, Richard Baxter suggests that religious liberty

tendeth to the destruction of an Army, to give liberty to all men to do their worst to draw them to Mutinies and Rebellion: It tends to the ruine of Families, that all have liberty to do their worst to tempt the Sonnes to theft and drunkennesse, and the Wife and Daughters to Whoredom: It tends to the destruction of the commonwealth, if there be liberty for all to perswade the people to sedition and Rebellion: And therefore it must tend to the destruction of the Church, and of mens Souls, and consequently of the Commonwealth in the chief respects, if all have leave to do their worst to preach up infidelity, Mahometanisme, Popery, or any false Doctrine or Worship, against the great and necessary truths (Baxter 1994, 27). 
However, throughout this period and to its end, writers defending tolerance, such as Sebastian Castellio, Samuel Pufendorf, and John Locke, consistently used this sort of argument to recommend that some divergent 'religious' views should be punished, on the grounds that they threatened the commonwealth or undermined civil order. Castellio takes it for granted that 'infidels' and 'atheists' need not be tolerated (Castellio 1935, 132), and favorably quotes John Brenz, who suggests that 'Anabaptism is not simply heresy, but has accompaniments which fall within the sphere of the civil government, for the Anabaptists teach that goods would be held in common. Now this tenet might perhaps produce an insurrection.' (p. 161.) Similarly, both Pufendorf and Locke argue that belief in and fear of God is necessary for moral order, that 'a man would not even be sociable if he were not imbued with religion' (Pufendorf 1991, 37), and that atheism is therefore 'a Crime, which for its Madness as well as Guilt, ought to shut a Man out of all Sober and Civil Society' (Locke 2002, 211). Locke thus suggests that some forms of religious belief (or unbelief) could have negative 'practical' consequences and consequently need not be tolerated by the commonwealth (he specifically targets particular Catholic and Muslim beliefs; see Locke 2003, 244-6).

Ideology produced within the Christian tradition never ceased to serve in the determination of and justification for what exactly constituted a potential threat to public order. That is, Christian ideology provided the criteria by which one could judge whether or not a belief or practice was threatening to public welfare. Luther did not think that citizens in a Lutheran state should be forced to adopt Lutheranism (they could not be forced to do so, since acceptance of the true faith took place only through the use of an uncoerced free will); however, he did claim that citizens should be forced to attend catechism courses that covered morality and other temporal matters:

when the teaching of the ten commandments and the catechism touches on politics and economics [...] people must be compelled to go to the sermons, so that they may learn there political obedience and social duties, never mind whether they believe in the gospel or not (quoted in Lecler 1960, 159).

Similarly, Althusius made the Decalogue the foundation of both 'ecclesiastical and secular' order, insofar as the 'first table' is the basis of knowledge about one's eternal welfare, and the 'second table' provides knowledge of 'justice, which concerns the use of the body and of this life' (Althusius 1964, 70). Spinoza insisted that the 'Divine Law' or the 'eternal truths' of 'true 
religion' found in the Jewish and Christian Scriptures concerned piety and the moral law; consequently, 'the practice of religion and the exercise of piety must accord with the peace and welfare of the commonwealth' (Spinoza 2001, 212; see also 51ff and 150ff). For Luther, Calvin, Althusius, Spinoza, and others, the Christian or Biblical traditions were the source of the moral norms necessary for civil order.

The defenders of tolerance did not object to this point. Pufendorf argued that the natural law necessary for civil order is contained in the Bible (Pufendorf 1991, 11). According to him, 'Christian morality [...] encourage[s] a good quality of civil life', and 'Christian virtues [...] do as much as anything to dispose men's mind to sociality [...]. [I]f you see anyone engaged in sedition and disrupting civil life, you may safely infer that the Christian religion may be on his lips but has never penetrated his heart.' (Pufendorf 1991, 9.) In his An Essay Concerning Human Understanding (1979), John Locke recommends an epistemological humility toward those things we cannot know, a practice that he believed would justify tolerance for a range of Christian doctrines, insofar as they involved uncertainties beyond the scope of possible human knowledge. However, this epistemological humility did not extend to certain essentials, which included the moral norms and virtues intrinsically linked by God to public welfare ( $p$. 69). Although these moral norms are in principle self-evident, most humans are insufficiently intelligent to intuit them. Locke explains that it was for this reason that God sent Jesus: "tis at least a surer and shorter way, to the Apprehensions of the vulgar, and mass of Mankind, that one manifestly sent from God, and coming with visible Authority from him, should as a King and Lawmaker tell them their Duties, and require their Obedience' (Locke 2002, 195). These essential moral norms revealed by Jesus are recorded in the 'infallible' scriptures (Locke 1979, 489). Consequently, it is necessary that children 'should learn perfectly by heart [...] The Lord's Prayer, the Creeds, and Ten Commandments', all of which should be done 'even before [children] can read' (Locke 1996, 117). In sum, for Locke the only way in which societies would be able to create the conditions for civil order or public welfare would be to habituate Christian moral norms into all citizens from childhood. Sebastian Castellio held a similar view. ${ }^{5}$

5 For Castellio, there were on the one hand uncertain matters of faith that were 'dubious', while on the other hand there were matters that were 'certain and to be believed' (Castellio 1935, 290). Certain matters that 'ought to be known', and which were 'necessary for the knowledge of God or the duty of man' (p. 291) included the 'precepts of love' found in 'the law and the prophets' and in the teachings of Jesus (p. 292). 
Even for defenders of tolerance, it never ceased to be the case that the Christian or Biblical traditions were understood as fundamental sources for the moral and legal norms required for civil order. It is no surprise, then, that tolerance had a relatively limited scope: it was rarely recommended for religious traditions that rejected the authority of the Jewish and Christian scriptures, and was never recommended for atheists.

In summary, what did not change during this time period includes the following. Political theorists consistently relied on the two spheres doctrine, and continued to claim that anything that constituted a threat to the commonwealth or the public order should not be tolerated. In addition, the justification for the two spheres doctrine and the determination of what constituted a threat to public order was consistently based on and justified by Christian ideology.

\section{What Did Change}

Despite the fact that many things did not change during this time period, some things clearly did, given that Europe looked very different at the end of it. There are three important changes that I will describe, that in some way account for the so-called 'rise of tolerance', 'freedom of conscience', and 'separation of church and state'. First, there was a new tendency to disassociate the identity of the state from that of the Christian institutions within its territory. Second, justifications for tolerance began to characterize particular Christian doctrines and practices as inessential or irrelevant. And third, justifications for tolerance increasingly conflated the spiritual/temporal and church/state binaries.

First, as Europe adjusted to the violence resulting from the Reformation, it became increasingly clear that maintaining or sharing an identity between states and Christian institutions was perhaps too costly. Early in this time period, because in many states the identity of the commonwealth was coterminous with a favored Christian institution, the presence of alternate institutions constituted a threat to public unity. When the state is a Lutheran state, citizens who pledge allegiance to another state's Christian institution are, for that reason, seditious traitors. One Lutheran prince, for example, claimed '[a]lthough we have no intention [...] of imposing on everyone what should be held or believed, nevertheless, in order to avoid any dangerous disturbance or trouble, we will neither recognize nor tolerate any sect or any faction in our principality' (quoted in Lecler 1960, 158). Erasmus insists that the Donatists, in Augustine's day, 'were more than heretics. They were 
seditious brigands.' (Castellio 1935, 170.) In addition, the revolutionary character of Anabaptist sects served as an important example of the fact that divergent sects could constitute a substantial violent threat to the public welfare and the unity of the state, as well as potentially violating the moral order therein. Henry Kamen seems to both admit and deny this fact in a brief passage summarizing his chapter on Anabaptism:

Complete separation of Church and State, indifference to the secular authority, and rejection of the use of force - these tenets made the Anabaptists a nuisance certainly, but not an explicit threat to the state. This at least was recognized by Philip of Hesse. But nearly all other religious and lay rulers were agreed on the employment of death against them. Their attitude seemed justified by the participation of revolutionary and non-pacifist Anabaptists in the Peasant War, and by the use of rebaptism by some rebels. (Emphasis mine; Kamen 1967, 61.)

Kamen goes on, on the very next page, to describe Anabaptists as 'sectarian', as well as 'often too exclusive and sometimes fanatical' (Kamen 1967, 62). How can Anabaptists be 'revolutionaries', 'rebels', and 'fanatical' besides, yet not be 'an explicit threat to the state'? Although Kamen is saved from contradicting himself by making a distinction between pacifist and non-pacifist Anabaptists, he clearly suggests that the non-pacifist Anabaptists were, in fact, a real, revolutionary threat to the social order. ${ }^{6}$ Given the Anabaptists' participation in the Peasant's War and the so-called 'Münster tragedy', in which Anabaptists seized power in the Westphalia city of Münster and instituted a 'communistic' regime until attacking forces invaded and killed everyone inside, it was difficult to see how the Anabaptists could be anything other than a threat to the social order. As Diarmaid MacCulloch suggests, the memory of these rebellious actions 'continued to provide the rationale for rulers to persecute and marginalize radicals, and added to their sense that order in society was something very fragile and in need of constant repressive vigilance' (MacCulloch 2003, 210).

The concern that allegiance to another social institution (Christian or otherwise) could constitute a threat to the unity of the commonwealth persisted even through Locke's writing - Locke failed to recommend tolerance of Catholics who maintained allegiances to the pope, insofar as Locke saw

6 As Max Weber suggests, however, pacifism itself can in some cases be considered 'anarchism' (see Weber 1958, 334). 
the latter as a foreign ruler of sorts. ${ }^{7}$ Thus it is important to note that the belief that allegiances to alternate or minority Christian institutions could, in some cases, constitute a threat to the public order did not change during this time period.

What did change, however, was the general ordering of social identities. It became pragmatically useful to reorder social identities and alliances in such a way that they need not be mutually threatening to one another. The politiques, who argued for tolerance on the grounds that it was politically expedient to tolerate diverse sects, reversed the position taken by previous political theorists. They came to the conclusion that the repression of divergent or radical sects was itself a threat to the public order. According to Quentin Skinner, for Jean Bodin, ' $[w]$ here good order is found to be in conflict with religious uniformity, the maintenance of good order must always be treated as the higher priority' (Skinner 1978, 254). In addition, according to Skinner, for Michel de l'Hôpital,

while the government may be said to have a duty to defend the established religion of the commonwealth, it has an even more compelling duty 'to maintain the people in peace and tranquility' [...]. Where these two duties collide, [de l'Hôpital] is now prepared to contemplate separating the fate of the kingdom from that of the Catholic faith, insisting that the fundamental question at issue 'is not about the maintenance of religion but about maintaining the commonwealth.' (Skinner 1978, 251.)

What l'Hôpital claims is not that allegiances to Christian institutions cannot be threatening to the public order, but only that when they are threatening to the public order, social identities must be reordered in a way so as to eliminate the threat. As Kamen notes, 'to alienate a vast minority in the realm by open religious persecution, threaten[s] the internal security and welfare of the country' (Kamen 1967, 197). Rather than divide their kingdom by violently suppressing a seditious minority group, rulers could render dissention no longer seditious by disjoining the state's identity from a denomination's identity.

7 This is implicit rather than explicit. Locke explicitly states, "[t]hat church can have no right to be tolerated by the magistrate, which is constituted upon such a bottom, that all those who enter into it, do thereby, ipso facto, deliver themselves up to the protection and service of another prince" (Locke 2003, 245). Although he gives an example of a Muslim offering allegiance to a 'mufti', I believe that Locke's contemporaries may well have read the pope as another 'prince' analogous to a 'mufti'. There is, however, no scholarly consensus on this point. 
This raises the following question: how was it that the determination of the 'security' and 'welfare' of the state could become divorced from the protection of certain Christian doctrines and allegiance to certain Christian institutions? Luther, for instance, would have claimed that the welfare of the state requires that false prophets be prevented from leading citizens away from the Lutheran faith. Similarly, Calvin claimed that the magistrate must protect the 'sheep' from the 'wolves'. Zagorin writes, '[w] as it reasonable, [Calvin] demanded, "that heretics should murder and poison souls with their false doctrines, and the sword ordained by God be prevented from touching their bodies, and the whole body of Christ be lacerated so that the stench of one rotten member should be untouched"' (Zagorin 2003, 81)? As I noted above, Baxter argued that providing liberty to divergent religious teachings led to mutiny, rebellion, the destruction of the family, theft, drunkenness, and 'whoredom'. Knox insisted that the divinely appointed magistrate needed to ensure that 'true teachers' instructed citizens 'in His true religion' (for Knox, 'true religion' was a specific form of Protestantism), and that teachers who 'deceive the people [...] may be removed and punished' by the magistrate (Knox 1994, 83). So what allowed these positions to become obsolete, and to be replaced by a position that considered most denominational differences as irrelevant to the public welfare? Since the appeal to public order or public welfare did not change in these arguments, what must have changed were the particular criteria used to determine what constituted public order. A more apt question, then, is how did it come about that the politiques' criteria for determining public order eventually replaced those of Luther and Calvin? Kamen suggests that this change was in part due to the turn away from theological 'dogmatism' (Kamen 1967, 202). I find this to be a rather tendentious characterization, and opt instead to pay closer attention to the discursive transformations that took place between Luther and Locke, and without recourse to rhetorical terms such as 'dogmatic'. This brings us to the second key change during this time period.

The second important change during this time period is that there began to appear, as a result of an internal dialogue among Christians, the deft application of a new justification for tolerance involving a reordering of Christian doctrines, with changes as to which were seen as essential or inessential. Some defenders of tolerance began to extend the category of 'inessential' doctrines to cover denominational differences; if denominational differences could theoretically be rendered irrelevant to one's eternal or civil welfare, the magistrate need not police them. Thus there arose among defenders of 
tolerance a sort of theological or doctrinal minimalism - tolerance could be extended to all who accepted the minimal essentials.

This rhetorical move appeared early during this period; Erasmus insisted early in the sixteenth century that social unity could be preserved if authorities insisted only on essentials, and allowed liberty for all inessential differences. ${ }^{8}$ For Erasmus, the distinction between essential and inessential was linked to the distinction between what was clear and unclear in the scriptures. ${ }^{9}$ Similarly, in the middle of the sixteenth century, Castellio recommended epistemological humility on those matters in the scriptures that were unclear or obscure. For Castellio, God's existence, that he should be worshipped, and the outlines of virtue and vice were certain, essential, and clear matters around which Christians could be united, but there was a great deal of dissention around obscure and (therefore unnecessary or inessential) doctrines that 'are not cleared up in Scripture' - 'concerning baptism, the Lord's Supper, justification, predestination and many other questions' (Castellio 1935, 294). Insofar as the differences between Catholicism, Lutheranism, and Calvinism (to which Castellio is specifically pointing in naming these particular 'obscure' doctrines) could be forced into this category of obscure or inessential matters, they could be considered irrelevant to any protections or regulations the magistrate might set in place.

Even those who were opposed to tolerance and supported state control of the church used this sort of argument. Early in the seventeenth century, Althusius claimed that the Decalogue was 'essential' (Althusius 1964, 142). Later in the seventeenth century, Baxter insisted that it was forbidden 'to impose any uncertain or necessary points of doctrine, discipline or worship', but that it was necessary for the magistrate to 'restore the primitive simplicity, by taking the Holy Scriptures in general as the sufficient Rule and Law of faith and worship'; 'let [the church] meddle with no controversies', he implored (Baxter 1994, 163-4). Many who either opposed tolerance or supported state control of Christian institutions used the essential/inessential distinction, but extended the term 'essential' to include a number

8 Erasmus suggests, in a letter to the Pope, "[t]he definition of dogmas should be reserved to a synod. Nor do I think it is necessary that the synod pronounce on each and every opinion but rather upon those matters that form the essentials of Christian doctrine." (Erasmus 1983, 331.)

9 Erasmus claims, in a letter to John Slechta, "it is my opinion that many would be reconciled with the Roman Church [...] if instead of wishing to fix and define every little detail, we were to let suffice what is clearly contained in the Scriptures and indispensable to salvation" (emphasis mine; Erasmus 1983, 208). 
of doctrines beyond those enumerated by the defenders of tolerance who deployed a theological minimalism.

Pufendorf, who enumerated a shorter list of essentials, argued that only the tenets of 'natural religion' were necessary for social order. For Pufendorf, natural religion required belief in God, belief in a certain understanding of the nature of God, a commitment to a certain type of worship of God, and a fear of God, without which morality and virtue would be impossible (this is summarized in a chapter titled 'On man's duty to God, or on natural religion'; see Pufendorf 1991, 39-45). Locke's position was virtually identical.

Spinoza (2001) had a sort of intermediate position, and distinguished between on the one hand doctrines about natural law and pious behavior that were universal, self-evident, essential (p. 51), eternal (p. 53), necessary (p. 146), and common (p. 159), on the other hand matters that were merely ceremonial (p. 51), superstitious (p. 144), controversial (p. 161), irrelevant (p. 162), or speculative (p. 229). Like Castellio, Spinoza placed the specifics of certain 'Christian ceremonies, namely baptism, the Lord's Supper, festivals, public prayers', etc., in the latter set, and therefore people were 'by no means bound by them' (p. 65). However, anyone who denied the 'few simple doctrines that Christ taught his people' (p. 144) and which were contained in the Bible - including a belief in God, a certain understanding of his nature, and a certain understanding of morality - was 'hardly human and close to being a beast' (p. 67). Like Pufendorf and Locke, Spinoza supported freedom of thought as far as it could go, but saw civil order as supported by a certain moral ideology; he therefore recommended state regulation of 'piety and religion' where they 'conform to the public good' (p. 216). Although Spinoza insisted that the state should regulate religion and Locke and Pufendorf denied it, the difference between their positions was incidental: for all practical purposes their positions on the centrality of the Bible for the rule of the commonwealth were identical.

In sum, while no one denied that the state should create the appropriate conditions for the essentials of natural law, Biblical virtue, and true religion to flourish, later reformers and defenders of tolerance would shift a number of doctrines from the category of 'essential' to the category of 'inessential' matters, rendering them irrelevant to state rule. Above, I posed the following question: how did it come about that the politiques' criteria for determining public order eventually replaced 'less tolerant' ones? The answer is not that Christian ideology became irrelevant for determining public welfare; rather, certain rhetorical devices were successful in recategorizing a specific and limited set of Christian doctrines and practices as irrelevant to public welfare. 
Those such as Luther and Calvin maintained that doctrines and practices unique to their own sects must be protected from competition - otherwise evil heretics could lead believers into immoral and anti-social behavior, or, worse, away from the truth and into the fires of hell. However, if those unique doctrines and practices were inessential for salvation and public welfare, then there was insufficient reason for the magistrate to impose them.

Above all, it is important to draw attention to the fact that the criteria used to determine which doctrines were 'essential' and which were 'inessential' were, for the most part, produced within and circulated by Christian institutions and Christian thinkers; as these rhetorical moves themselves depended on a particular form of Christian ideology, they justified the extension of tolerance only to a relatively homogeneous group. In several states, differences concerning the Eucharist and baptism (and many other things about which there was little consensus) were successfully characterized as inessential matters and therefore unnecessary for the state to protect. However, as Zagorin notes, these rhetorical moves usually presumed a consensus on the 'essentials', such as 'the role of Christ as savior and redeemer", and the "obvious moral truths on which no one disagrees" (Zagorin 2003, 113). These obvious moral truths included the common-sense truism that atheists were naturally immoral, liars, and lawbreakers (as well as a number of patriarchal social norms; see 'On the duties of marriage' in Pufendorf 1991, 120ff). Christian ideology on these particular matters was certainly not irrelevant. Therefore, the reason there could be a shift from one criterion for the assurance of public welfare (securing the proper conditions for specific denominations to flourish) to another (protecting the peace, independent of denominational differences) was the result of a shift not away from Christian 'dogmatism' but from one type of Christian 'dogmatism' to another. The rise of a more universalist or theologically minimalist form of Christianity contributed to making certain denominational differences irrelevant to discussions of public welfare, but did not render Christianity as such irrelevant to these discussions. In addition, these rhetorical moves obscure the fact that theological minimalism, although claiming to be universal, was for the most part simply the local ideology of early modern Protestant Christians. As James Tully perceptively notes, the failure 'in Catholic Europe, let alone in non-Christian societies', of this Protestant universalism 'belies its university [sic]' (see 'Editor's Introduction' in Pufendorf 1991, xxiii).

Thus the characterization of this time period as passing from a dogmatic regime to a non-dogmatic one is inaccurate and misleading. It is simply not true that Christian ideology was used at the beginning of this time period 
to determine the shape of the public order and the public good, but that, by the end, it had become irrelevant. It is likewise not the case that Christian institutions initially held a hegemony over state functions, but then later that hegemonic control was withdrawn. Rather, there was a 'breakdown of one type of authoritarianism [...] [which] led to another the temporary victory of another authoritarianism' (Hill 2000, 42). This does not mean that the shift that did occur offered no practical gains; clearly, the savage persecution of some Christian groups was lifted. This does mean, however, that a provincial ideology, albeit of a different sort, was still used to determine and justify the shape of public welfare, and to determine exactly which Christian doctrines were relevant or irrelevant for making this determination. This is why, as I noted above, the justifications for tolerance went only so far as to protect a relatively homogeneous citizenry. Zagorin claims, when describing the rise of the category of inessential matters, '[t]he distinction between the essential and the obscure, uncertain, and debatable parts of the Christian religion implies a charitable acknowledgement of the legitimacy and inevitability of dissent and differences' (emphasis mine; Zagorin 2003, 113). This overly sanguine account silently passes over the fact that these new categories were still based on the 'Christian religion', but substituted a new provincial orthodoxy and new certainties for old ones. The distinction between essentials and non-essentials, which Zagorin praises with the rhetoric of 'charity', does not question the authority of Christianity in general, does not question the authority of Christian ideology in general to determine the shape of the state, and does not question the authority of the Christian scriptures. Despite this rhetoric of 'charity', then, these discourses on tolerance remained ideological buttresses for Christian privilege.

The third important change during this time period was the rhetorical slippage back and forth between the spiritual/temporal and religion/state binaries. An important shift in the use of the spiritual/temporal binary was subtly made when defenders of tolerance began manipulating the content of 'spiritual matters' in ways that were not warranted by their Augustinian anthropology. This effected a conceptual departure from the Augustinian anthropology, although it remained the implicit justification of the two spheres doctrine. The Augustinian anthropology involved the following homologous taxonomies:

\author{
Soul / Body \\ Spiritual / Temporal \\ Invisible Church / Visible Church
}


The early modern defenders of tolerance used these distinctions side by side with the following taxonomy, which was not homologous with the others:

\section{Church / State}

The 'spiritual/temporal' and 'church/state' taxonomies are not homologous, because, for the Augustinian anthropology, the 'church' is made up of both the 'visible church' and the 'invisible church':

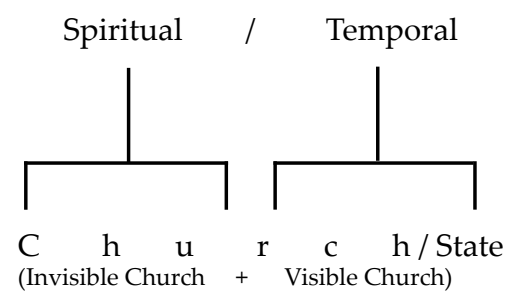

However, in a crucial move, defenders of tolerance began to conflate the 'invisible church' with the 'visible church' in attempting to extend the associations about the impossibility of interference from the former to the latter. For Augustine, the invisible church included those who have freely accepted God's grace; because this is an invisible and freely chosen transaction between individuals and God, the magistrate, in principle, cannot interfere. ${ }^{10}$ The reformers who wanted the local magistrates to stop interfering with their own 'visible churches' conflated the terms 'invisible' with 'visible', forcing the idea that the magistrate cannot interfere with the 'invisible church' to slide over and apply to the 'visible church' as well:

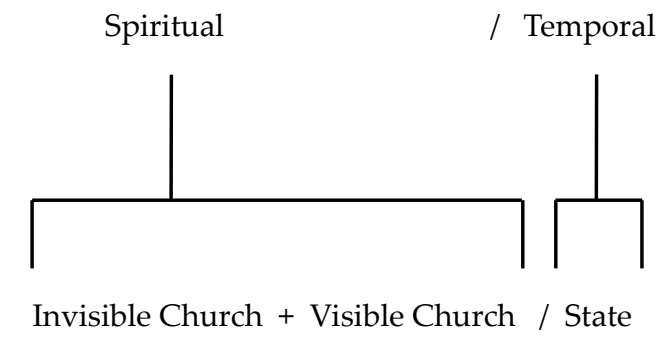

10 In one form or another, this was affirmed by Luther (1991, 23ff), Calvin (1991, 50; on Calvin, see also Castellio 1935, 271), Hooker (1989, 172ff), Althusius ("faith [...] [cannot] be coerced"; 1964, 167), Baxter ("We Grant that the Consciences of men are out of the reach of the Magistrates judgment"; 1994, 20), Spinoza ("it is impossible for the mind to be completely under another's control" 2001, 222), and Locke ("The care of souls cannot belong to the civil magistrate, because his power consists only in outward force"; 2003, 219). 
Notice that in the former rhetorical configuration, the 'visible church' was on the right and was associated with the temporal sphere; in the latter configuration, the 'visible church' has slipped to the left, and is therefore associated with the word 'spiritual' rather than 'temporal'. This slippage allowed these thinkers to slide back and forth between the idea of religion as an invisible relationship to God and the idea of religion as an institution in the world. Spinoza, for instance, on one page claims that because human minds are beyond the control of the magistrate and the differences between sects concern inessentials, what 'religion or sect' one belongs to is 'irrelevant in a court of law' (Spinoza 2001, 228), yet on the next page insists that religion concerns the outward observance of piety ('both in religious and secular spheres') and should therefore be controlled by the state (p. 229). Similarly, on the one hand Locke insists in 'A Letter concerning Toleration':

[T] he church itself is a thing absolutely separate and distinct from the commonwealth. The boundaries on both sides are fixed and immutable. He jumbles heaven and earth together, the things most remote and opposite, who mixes these societies, which are, in their original, end, business, and in every thing, perfectly distinct, and infinitely different from each other. (Locke 2003, 226.)

[The church and the worship of God is outside] the reach of the magistrate's jurisdiction, because $[. .$.$] they have no connexion at all with civil affairs. The$ only business of the church is the salvation of souls: and it no ways concerns the commonwealth. (Locke 2003, 233.)

Yet, elsewhere he insists that one of the great 'ends of religion' concerns the propagation of the tenets of the natural law necessary for civil order and public welfare (see above and Locke 2002, 74ff). This slippage between 'religion' as an invisible relationship to God and 'religion' as a social institution made it possible for defenders of tolerance to extend the associations connected with former to the latter; they could therefore pass from a descriptive claim, that religion (as an invisible, spiritual matter) could not be subjected to the use of force, to the non sequitur normative claim that religion (as a visible, temporal institution) should not be subjected to the use of force.

Notice historian Joseph Lecler's slippage between these two 'churches' in Toleration and the Reformation. At one point, Lecler quotes Valentine Weigel's criticism of Luther: 'The Holy Church, gathered together in faith and charity, is invisible; it is ruled, not by any man, but by the Holy Spirit, and no one can 
point with the finger to the place where it is' (emphasis mine; Lecler 1960, 187). Lecler goes on to make the following comments: 'Such a conception of the church excludes [1] any recourse to violence in order to impose belief, and [2] any pretension of a magistrate, even a Christian one, to exercise any authority whatever in religious matters' (emphasis mine; Lecler 1960, 187). Whereas Augustinian theology would, in fact, theoretically exclude the first type of interference, it would not necessarily exclude the second, insofar as 'religious matters', generally speaking, include not only what is 'invisible', but also what is 'visible', 'temporal', and 'bodily'. According to the classic two spheres doctrine, the magistrate has both the duty and the right to govern bodies in the visible world. Lecler's comment that the magistrate is not justified in interfering with any 'religious matters' follows only if his readers ignore the slippage from the specie 'invisible church' to the genus 'religious matters'.

I am not the first to notice this rhetorical slippage; I know of one other place where it is noted. Hooker draws attention to it in Of the Laws of Ecclesiastical Polity, where he defends state control of the Church of England by refusing to collapse the 'invisible' and 'visible' categories into the category of 'spiritual' matters. Hooker maintains that the head of the invisible and inward church is Christ, but goes on to argue that the church is made up of both invisible and visible parts, and that the latter is subject to human control unlike the former: 'We [...] truly and rightly discern a power external and visible in the Church exercised by men and severed in nature from that spiritual power of Christ's own regiment, which power is termed spiritual because it worketh secretly inwardly and invisibly' (Hooker 1989, 173).

This rhetorical slippage permits the associations hung on the idea of the 'invisible church' (which cannot be interfered with) to be forced onto the idea of the 'visible church' and 'religion' in general. These defenders of tolerance should be understood as sliding from the spiritual/temporal or invisible/visible taxonomy to the church/state taxonomy, and extending the associations connected with the terms 'spiritual' and 'invisible' to the term 'church' (and 'religion') in general. This rhetorical slippage contributed to making invisible the continuing authority of Christian ideology for the state during this time period. Although it eventually came about that there occurred a separation of 'religion' from the 'state' at the top levels (insofar as ecclesiastical orders no longer had control of kings and vice versa), the 'visible church' was clearly active in socializing the bodies of citizens and magistrates with Christian ideology. As a result, atheism remained a crime after the so-called 'separation of church and state'; the 'obviousness' of the threat of atheism 
for society is inexplicable apart from the influence of Christian ideology on state legislation. However, as the 'visible church' began to be covered by the associations previously hung on the 'invisible church' (which theoretically could have nothing to do with state institutions, and which was impervious to state interference), the connection between the visible church and state institutions became difficult to intuit. I would go so far as to suggest the following: this rhetorical slippage between 'visible church' and 'invisible church' is the origin of the modern myth that 'religious' institutions are by their very nature apolitical (on religion as 'apolitical' in contemporary discourses, see Martin 2007a, 2007b, and Martin forthcoming). Unfortunately, this myth has contributed to preventing political philosophers and historians of 'secularism' from seeing the continuing influence of Christian ideology on the state.

Many contemporary political theorists are interested in studying how the 'privatization of religion' changed the face of Europe, and resulted in the 'separation of church and state'. However, I think it is more important to note that the application of the language of 'privatization', insofar as it fails to bring into relief the circulation of power from civil to state institutions brought about through private education, socialization, and the distribution of ideology, may in fact serve the interests of those 'privatized' civil institutions whose ideology is thereby rendered theoretically inconsequential, undiagnosed, and free to circulate invisibly.

\section{Conclusion}

At the end of the period stretching from Luther to Locke, according to the popular view of the so-called rise of tolerance, the defenders of tolerance took a position much like the following: the state has no right to interfere in citizens' spiritual relationship with God, unless their religion disturbs the public good or threatens the commonwealth; the spiritual and worldly realms should therefore be held separate. However, I have shown that this position is identical to that of the apparent enemies of tolerance, such as Luther and Calvin. What changed politically, following the Protestant Reformation, is not best described as the gradual separation of 'church' from 'state'. Rather, there was first a disjoining of state identity from the identity of specific Christian denominations - this shift allowed diverse Christian institutions to exist without their mere existence constituting a seditious or rebellious threat to state unity. Second, there arose a transformation within Christian ideology concerning which Christian doctrines were irrelevant for public welfare and which were not. This allowed the determination of 
the public welfare of the state and its citizens to be divorced, not from all Christian doctrine, but only from those doctrines that could be successfully categorized as 'inessential'. Last, there was a rhetorical slippage in discourses on religion, which extended the rhetorical associations connected to the term 'spiritual' to all 'religious' matters; this slippage contributed to the characterization of religion as apolitical. Above all, at no point did Christian ideology cease to be a foundation and justification for the shape of the public order. Is it any surprise that atheism did not occupy a protected sphere? There was never a withdrawal of Christian ideology from its hegemonic position. Rather, there was a move from a hegemony of one sort of Christian ideology to a hegemony of another sort.

I want to offer a rather important caveat: this does not mean that the discourse on religion as apolitical does no work other than to mask the political nature of religion. It is clear that some political work is accomplished by declaring that there is or should be a 'separation of church and state' - many laws legitimated by Christian ideology have been repealed or overturned on the grounds that there should be such a separation (such as laws requiring all businesses to be closed on Sunday), and lawyers before the American Supreme Court know they have to cite the law code or the constitution rather than the Bible to persuade their audience. My intention is not to argue that the discourse of separation does no work of any sort; I merely want to argue that there is not, in fact, a separation.

The inability of the popular myth to take into account the continuing Christian hegemony in early modern Europe despite the rise of the so-called separation of church and state can be accounted for in part by the masking effect created by the rhetorical slippage that blurred the distinction between 'visible church' and 'invisible church', causing associations connected to the latter to be applied to the former, and resulting in all matters of 'religion' being dismissed as apolitical or as inconsequential to the state. The use of the church/state dichotomy and the 'separation of church and state' rhetoric fails to bring into relief the actual changes that took place during this time period for two fundamental reasons. First, the slippage from the spiritual/ temporal and soul/body dichotomy to the church/state dichotomy obscures the fact that churches are social, bodily, temporal institutions. Christians consistently maintained that it is the duty of churches to teach and regulate morality. This included training, disciplining, and habituating Christian bodies to believe and desire certain things; these Christian bodies were also social and political actors: princes, magistrates, and citizens, all of whom acted on their training, discipline, and habituation. As a result, in no way 
were Christian institutions substantially separated from the shape of state regulations. Second, the church/state dichotomy disguises the continuing authority of Christian ideology in determining and justifying the shape of the state. Even if the identity of the state was disjoined from the identity of a particular local denomination, this in no way meant that Christian institutions and Christian ideology ceased to be authoritative. In sum, even if priests ceased to hold direct control over princes, the powers of Christian institutions and state institutions were imbricated and radically inextricable. Although the relationship between Christian institutions and state institutions changed during this time period, that change is not best described as a 'separation', but as a rearticulation of the circulation of power from one to the other. There was at most only a reversal of the direction in which power circulated - the shift from a medieval paradigm to a liberal one brought about a bottom-up rather than a top-down circulation of power.

As Fitzgerald notes, in the discourses on 'religion' that were regnant before the rise of toleration, '[f] $]$ aith is not confined to the inner, individual, private assent to a doctrine of personal salvation; it is a commitment to practice the Christian disciplines of civility, which are collectively imagined and policed' (Fitzgerald 2007a, 156). The difference between my view and Fitzgerald's is that I have shown that this continued to be the case even after the 15th century, although the language of privacy made it seem otherwise. I part ways with Fitzgerald when he suggests 'that there are many ways in which religion and politics today have been defined that make them mutually exclusive and inhabiting distinct domains' (emphasis mine; Fitzgerald 2007a, 173). Despite the rhetoric to the contrary, religion and politics are not distinct domains today. The early modern discourses on religion and politics did not usher in 'new configurations and replace previous categories and configurations' (p. 186) - on the contrary, these new discourses largely masked existing configurations.

This redescription of the changes that took place during this time period is relevant for at least the following two reasons. First, as Russell McCutcheon has rightly noted,

What should attract our attention [...] is not that such discourses on tolerance are hypocritical [...] or that all discourses on tolerance contain an inevitable element of intolerance, but instead how easily boundary policing and maintenance are glossed over when like-minded - or, better phrased, like-interested and like-organized - people converse on the so-called common good and supposedly civil society (McCutcheon 2003, 267). 
A great deal of social control can be obscured when public figures champion tolerance, insofar as tolerance rhetoric intrinsically backgrounds or makes invisible the criteria of inclusion and exclusion employed. Everyone, even libertarians, must draw constraints - the trick is to identify how and where the constraints are drawn, even when social actors rhetorically deny - usually with the language of freedom, liberty, tolerance, deregulation, etc. - that they are drawing constraints.

Second, as I have noted, the language of 'separation of church and state' and 'privatization of religion', which reinforces the view that religion is apolitical, contributes to obscuring the incredible power of so-called 'private' institutions, institutions that, as a result of 'freedom of religion', are free to socialize a citizenry with a variety of norms, values, discourses, and ideologies that have a wide range of social and political consequences. The 'separation of church and state' language obscures the political import of the circulation of ideology. During the early modern period, Christian privilege was regnant and atheism was criminalized, which is only understandable in light of the circulation of power and ideology from the so-called 'private sphere' to the so-called 'public sphere'. Today, to offer only one example, the status of the rights of gays and lesbians cannot be understood apart from the circulation of power and ideology from civil institutions to public ones. This conclusions is not different from the one arrived at by Alexis de Tocqueville, almost two centuries ago. At one point de Tocqueville suggests, in a passage on the significance of religion in America:

[I]n the United States, religion governs not only behavior but extends its influence to men's minds [...]. Among Anglo-Americans there are some who profess Christian dogmas out of belief, others because they are afraid they might appear to lack belief. So Christianity reigns without obstacles by universal consent. (de Tocqueville 2003, 341.)

At another point de Tocqueville asks,

when a man or a party suffers from an injustice in the United States, to whom can he turn? To public opinion? This is what forms the majority. To the legislative body? That represents the majority and obeys it blindly. To the executive power? That is appointed by the majority and serves as its passive instrument. To the public police force? They are nothing but the majority under arms. To the jury? That is the majority invested with the right to pronounce judgments; the very judges in certain states are elected by the 
majority. So however, unfair or unreasonable the measures which damage you, you must submit. (de Tocqueville 2003, 294-5.)

His conclusion? 'If ever freedom is lost in America, blame will have to be laid at the door of the omnipotence of the majority, which will have driven minorities to despair' (de Tocqueville 2003, 304).

Democratic rule structurally permits the circulation of power from the so-called private sphere to the public sphere, yet the liberal language of 'separation' and 'privatization' makes it difficult to bring into relief that circulation of power. If we want to draw attention to the possible abuses brought about by the 'omnipotence of the majority', we should replace our use of the religion/state and public/private binaries with a set of discursive tools that better draw attention to the actual intercourse of power between those institutions colloquially called 'religions' and the 'state'.

\title{
Bibliography
}

\author{
Althusius, Johannes \\ 1964 The Politics of Johannes Althusius. Trans. by Frederick S. Carney. Boston: \\ Beacon Press.
}

\section{Arnal, William}

2001 The Segregation of Social Desire: 'Religion' and Disney World. - Journal of the American Academy of Religion 69/1: 1-19.

\section{Asad, Talal}

1993 Genealogies of Religion: Discipline and Reasons of Power in Christianity and Islam. Baltimore: Johns Hopkins University Press.

\section{Augustine}

1964 On Free Choice of the Will. Trans. by Anna Benjamin. Indianapolis: Bobbs-Merrill.

1997a Nature and Grace, in The Works of Saint Augustine: A Translation for the 21st Century Volume 23, Answer to the Pelagians, Volume 1. Hyde Park, New York: New City Press.

1997b The Spirit and the Letter, in The Works of Saint Augustine: A Translation for the 21st Century Volume 23, Answer to the Pelagians, Volume 1. Hyde Park, New York: New City Press.

1999 Grace and Free Choice, in The Works of Saint Augustine: A Translation for the 21st Century Volume 26, Answer to the Pelagians Volume IV. Brooklyn: New City Press. 


\section{Baxter, Richard}

1994 A Holy Commonwealth. Ed. by William Lamont. Cambridge: Cambridge University Press.

\section{Calvin, John}

1991 On Civil Government. - Luther and Calvin on Secular Authority. Ed. and trans. by Harro Höpfl. Cambridge: Cambridge University Press.

\section{Carrette, Jeremy \& Richard King}

2005 Selling Spirituality: The Silent Takeover of Religion. London: Routledge.

\section{Castellio, Sebastian}

1935 Concerning Heretics: Whether they are to be persecuted and how they are to be treated, A collection of the opinions of learned men both ancient and modern. Ed. by Roland Bainton. New York: Columbia University Press.

\section{Erasmus}

1983 The Essential Erasmus. Ed. and trans. by John P. Dolan. New York: Meridian.

\section{Fitzgerald, Timothy}

2003 'Religion' and 'the Secular' in Japan: Problems in History, Social Anthropology, and the Study of Religion. - Electronic Journal of Contemporary Japanese Studies 10 July 2003 (available online at www. japanesestudies.org.uk/discussionpapers/Fitzgerald.html\#1).

2007a Discourse on Civility and Barbarity. Oxford: Oxford University Press.

2007b Religion and the Secular: Historical and Colonial Formations. London: Equinox Publications.

\section{Gauchet, Marcel}

1997 The Disenchantment of the World: A Political History of Religion. Trans. Oscar Burge. Princeton: Princeton University Press.

\section{Hacking, Ian}

1999 The Social Construction of What? Cambridge, Mass.: Harvard University Press.

\section{Hill, Christopher}

2000 Toleration in seventeenth century England: theory and practice. - Susan Mendus (ed.), The Politics of Toleration in Modern Life, 27-44. Durham: Duke University Press.

\section{Hooker, Richard}

1989 Of the Laws of Ecclesiastical Polity. Ed. by Arthur Stephan McGrade. Cambridge: Cambridge University Press. 


\section{Kamen, Henry}

1967 The Rise of Toleration. New York: McGraw-Hill.

\section{Kaplan, Benjamin J.}

2007 Divided by Faith: Religious Conflict and the Practice of Toleration in Early Modern Europe. Cambridge, Mass.: Harvard University Press.

\section{Knox, Richard}

1994 On Rebellion. Ed. by Roger A Mason. Cambridge: Cambridge University Press.

\section{Lecler, Joseph}

1960 Toleration and the Reformation, 2 Vols. Trans. by T. L. Westow. New York: Associations Press.

\section{Lincoln, Bruce}

2003 Holy Terrors: Thinking about Religion after September 11. Chicago: University of Chicago Press.

\section{Locke, John}

1979 An Essay concerning Human Understanding. Ed. by Peter H. Nidditch. Oxford: Oxford University Press.

1996 Some Thoughts Concerning Education and Of the Conduct of the Understanding. Ed. by Ruth W. Grant and Nathan Tarcov. Indianapolis: Hackett Publishing Company.

2002 John Locke: Writings on Religion. Ed. by Victor Nuovo. Oxford: Oxford University Press.

2003 Two Treatises of Government and A Letter Concerning Toleration. Ed. by Ian Shapiro. New Haven: Yale University Press.

\section{Luther, Martin}

1991 On Secular Authority - Harro Höpfl (ed. and trans.), Luther and Calvin on Secular Authority, 1-46. Cambridge: Cambridge University Press.

\section{MacCulloch, Diarmaid}

2003 The Reformation: A History. New York: Penguin Books.

\section{Martin, Craig}

2007a Configured for Exclusion: Characterizations of Religion in Liberal Political Philosophy. - Method and Theory in the Study of Religion 19/1-2, 38-172.

2007b On 'Using Religion,' Or, How to Make Descriptions Carry Imperatives. - CSSR Bulletin 36/4.

2008 A Review of Timothy Fitzgerald's Discourse on Civility and Barbarity. - Journal for Cultural and Religious Theory 9/3, 22-7. Available at http://www.jcrt.org/archives/09.3/martin.pdf

2009 Delimiting Religion. - Method and Theory in the Study of Religion 21, 157-76. 
forthcoming Masking Hegemony: A Genealogy of Liberalism, Religion, and the Private Sphere. London: Equinox Publishing.

McCutcheon, Russell T.

2003 The Discipline of Religion: Structure, Meaning, Rhetoric. London: Routledge.

Miller, Peter \& Nikolas Rose

2008 Governing the Present. Cambridge: Polity Press.

Pufendorf, Samuel

1991 On the Duty of Man and Citizen. Ed. by James Tully. Trans. by Michael Silverthorne. Cambridge: Cambridge University Press.

Rawls, John

1996 Political Liberalism. New York: Columbia University Press.

Skinner, Quentin

1978 The Foundations of Modern Political Thought, Volume 2: The Age of Reformation. Cambridge: Cambridge University Press.

\section{Spinoza, Baruch}

2001 Theological-Political Treatise, Second Edition. Trans. by Samuel Shirley. Indianapolis: Hackett Publishing Company.

\section{de Tocqueville, Alexis}

2003 Democracy in America and Two Essays on America. Trans. by Gerald E. Bevan. New York: Penguin Books.

\section{Weber, Max}

1958 From Max Weber: Essays in Sociology. Ed. and trans. by H. H. Gerth \& C. Wright Mills. Oxford: Oxford University Press.

Witte, John Jr.

2002 Law and Protestantism: The Legal Teachings of the Reformation. Cambridge: Cambridge University Press.

\section{Zagorin, Perez}

2003 How the Idea of Religious Toleration Came to the West. Princeton: Princeton University Press. 